milling and baking industries. Value in wheat depends chiefly on the character and amount of the protein (gluten) it contains, but whereas the former is essentially an inherited factor, the latter may be considerably influenced by environmental conditions. The time which elapses between the formation and ripening of the kernel practically controls its gluten content-the shorter the period the higher the percentage-so that seasonal conditions such as high temperatures and absence of excessive moisture during the later stages of development, which tend to hasten ripening, result in a valuable high-protein wheat. Conversely, a starchy grain is produced if climatic conditions tend to prolong growth during this period. The richness of the soil, even as regards its nitrogen content, does not appear to have much influence on the quantity of protein in the grain, but its moisture absorbing capacity may be of considerable importance as it is necessarily closely associated with the rate of ripening of the crop. From data which have been collected over a period of twenty. eight years at a number of stations in Canada, it has been deduced that the excellent quality of the wheats from the prairie provinces is largely to be attributed to the favourable seasonal conditions that obtain, and not solely to the selection of the most suitable varieties for that district.

\section{Forest Products Research}

THE annual report of the Forest Products Research Board with the report of the Director of the Forest Products Research Laboratory, Princes Risborough, for the year 1933 has recently been published (London: H.M. Stationery Office. 1934). In a general statement, the Director notes that the progress of timber research has been satisfactory, whether regarded from the point of view of the actual results achieved or from the value of the results when applied in the timber-using industries and professions. Sir Ralph Pearson retired from the post of director during the year, and Mr. W. A. Robertson, late of the Indian Forest Service, was appointed. The report states that there is evidence of the increasing interest taken by industry in the activities of the Laboratory. The work carried out during the year on seasoning of timber, both kiln and air-seasoning, on steam bending, the structure and mechanical strength of wood and on preservation, is summarised. As a result of investigation work, it is stated that "there is no material difference between old and new timbers from the point of view of shrinkage and expansion", thereby disproving a common belief. Investigations were carried on in connexion with dry rot and insect damage. Tests were also carried out on the cricket bat willow.

\section{Birefringence of 'Viscacelle'}

Dr. N. H. Hartshorne, of University College, Swansea, writes: "With reference to my letter on the birefringence of 'Viscacelle' in the issue of NATURE of February 16 (p. 269), my attention has been directed to a note on the birefringence of 'Cellophane' contributed by Mr. Arthur M. Grundy to Watson's
Microscope Record in 1931 (Sept., p. 22). The name 'Cellophane' is commonly, though mistakenly, used as a general term for artificial cellulose sheet, and as Mr. Grundy did not state the source of his material, I am uncertain as to its exact nature. It was, however, doubtless very similar to, if not identical with 'Viscacelle'. He noted the uniformity of its optical character, and the fact that specimens of different thicknesses gave appropriately different polarisation colours, but he gave no data for the relative retardations associated with different thicknesses. $\mathrm{He}$ expressed the view that the optical uniformity of the material ruled out stress as a cause of its double refraction. As regards 'Viscacelle', I do not think that the double refraction is due in any degree to stress in the finished material, but, as I indicated in my letter, the stress involved in the spinning process (that is while the material is being drawn from the spinning slot into the coagulating bath) almost certainly causes an orientation of the cellulose molecules, and this accounts for the observed direction of 'slow' vibration. I regret that I did not see Mr. Grundy's note earlier, and I gladly acknowledge his prior discovery of the double refraction of artificial cellulose sheet."

\section{Native Chinese Drugs of Animal Origin}

REMEDIES derived from the animal kingdom bulk large in the old Chinese literature, and three instalments dealing with this Chinese materia medica, compiled by Mr. Bernard E. Read, assisted by Chinese scholars, have been published by the Peking Natural History Bulletin. The first instalment, containing the 'animal drugs', and the second the 'avian drugs', were issued some time ago, and now the third dealing with 'dragon and snake drugs' has been published ("Chinese Materia Medica". 7 : "Dragon and Snake Drugs". By Bernard E. Read. Pp. $66+6$ plates. Peiping : The French Bookstore, 1934. 1.50 dollars). Besides products derived from snakes, crocodiles, lizards and others, preparations from the fossilised bones of gigantic extinct saurians are included. Attempts are made to identify the creatures mentioned in the old works, and a Chinese index is appended. The whole forms a scholarly work of considerable interest and importance.

\section{British Mosquitoes}

A REVISED second edition of the pamphlet entitled "British Mosquitoes and their Control", Economic Series 4A, published by the British Museum (Natural History), has recently appeared. The authors, Messrs. F. W. Edwards and S. P. James, describe the characters and the habits of the twenty-eight species of these insects found in Britain. Measures for the control of mosquitoes and their larvæ are also described, together with means of protection against bites of the insects. The object of the pamphlet is to assist medical officers and others engaged in mosquito control with up-to-date information. It is obtainable, price $4 d$, from the British Museum (Natural History), Cromwell Road, London, S.W.7, or through booksellers. 